\title{
Industry-Based Learning
}

\author{
Kathy Henschke and Patrick Poppins \\ School of Business Information Technology, RMIT University, Australia
}

\begin{abstract}
Research from the fields of adult learning, workplace education, professional development, organisational learning and co-operative education are drawn on to identify elements that should be considered in the design, implementation, management and sustained improvement of co-op programs. Each work placement is unique meld of stakeholders, the job and the organisational context. Key factors that promote learning in the workplace include the engagement of the work place supervisor in the student's professional development; the learning environment within the organisation; and the student's own motivation, abilities and learning orientation: It is proposed that information systems delivering co-op programs need to manage: (a) the development and performance of industry partnerships, (b) the relationships between key stakeholders; and (c) the professional skills development and learning.
\end{abstract}

Keywords: Information management systems, Co-operative education, ICT professionals, employability skills, workplace learning, professional development

\section{INTRODUCTION}

Businesses and governments look to educational institutions to prepare individuals that are job-ready and have the ability to grow in the constantly changing workplace. Co-operative education programs (co-op) or sandwich years within higher education institutions, place students in long term paid or unpaid employment in a relevant job for up to 12 months. These placements aim to provide students with context-based, experiential learning opportunities.

There are a number of stakeholders involved in co-operative education programs: the employers who recruit and employ the student for the period of the co-op placement; the students who take on the job; the co-op personnel who develop and maintain the relationships between the employers, the students and the university; the work-based supervisors and/or mentors who guide the students during the placement; the academics

Please use the following format when citing this chapter:

Henschke, K. and Poppins, P., 2009, in IFIP International Federation for Information Processing, Volume 292; Evolution of Information Technology in Educational Management; Eds. Tatnall, A., Visscher, A., Finegan, A., O’Mahony, C., (Boston: Springer), pp. 169-180. 
who teach the students before and after the co-op year; the university management that resource the programs; and the professional bodies who accredit the degree programs.

A literature review uncovered differences of opinion on the value of coop programs. In general, most students gained confidence and self-concept; developed social skills; increased their practical knowledge and skills - all of which enhanced their employment opportunities (Waryszak 2000). However some, students returned to study disillusioned by their work experience. Many employers felt academic programs were not preparing the students adequately with essential skills to be competent in the work placement (Howard 2005; Multimedia Victoria 2005). While many in the academic community viewed co-op practice as limited to vocational development (Cates and Jones 1999, Howard 2005) and a drain on resources (Jancaukas et al. 1999). Academic staff involved in co-op programs reported feeling their work was undervalued and not recognised or rewarded through university promotions. In these cases, the commitment by academics to coop was sometimes found to take a relatively low priority in their curriculum and work planning (Weisz 1995) and the student learning in co-op often left to chance (Reeders et al. 1999).

The diversity of stakeholder views highlights the inherent difficulties of managing co-op programs. Coll and Eames (2004) observed that co-op programs designed with objectives that are relevant and appropriate to all parties involved, are far more likely to be successful and sustainable. With the growing area of interest (and concern) to governments, industry and universities of the importance of generic employability skills in graduates, it is proposed that co-op programs be designed, delivered and managed around the shared purpose of developing employability skills of the students.

This paper presents the findings of an extensive literature review that investigates the contribution of co-op work placements to the development of employability skills. Key processes needed to manage co-op programs, focussed on developing these skills, are identified. These processes are used in investigating a co-op program found within an existing undergraduate program at an Australian university, to determine its efficacy in developing employability skills.

In the next section the nature of employability skills and how they are developed are explored.

\section{THE NATURE OF EMPLOYABILITY SKILLS}

The past 20 years has seen Australian universities making significant efforts to enhance the graduate outcomes of their students by providing them with opportunities to develop generic employability skills within curricula. The Department of Education, Employment and Workplace Relations (DEST) published a report in 2002 in which it identified generic employability skills as: personal attributes of loyalty, commitment, honesty and 
integrity, enthusiasm, reliability, personal presentation, commonsense, positive self-esteem, sense of humour, balanced attitude to work and home life, ability to deal with pressure, motivation and adaptability; and eight key generic skills: communication; team work; problem-solving; initiative/ enterprise; planning and organisation; self-management; learning; and technology (DEST 2002).

An earlier report funded by the Department of Employment, Training and Youth Affairs (DETYA) titled Employer Satisfaction with Graduate Skills (DETYA 2000) noted that “... a large proportion of applicants for positions are considered unsuitable" (p.vii) identifying key skill deficiencies of graduates in the areas of oral business communication; creativity and flair; problem solving; independent and critical thinking; and understanding of business practice.

These deficiencies are attributed to a lack of understanding of the nature of generic skills and how they are acquired. Beckett and Hager (2002) propose generic skills be examined within a context-specific, relational perspective. The relational view sees generic skills linking the abilities of individuals (knowledge, skills, dispositions, values) to the demands, tasks and activities that individuals undertake (Gonczi 2004). How a task is completed is influenced by the context it is found in. The interplay of cultural, political, social and economic factors makes the situation each task is found in, unique. The ways generic skills cluster are strongly shaped by particular features of the context in which the work is carried out Hager (1997) cited in Beckett and Hager (2002).

From this perspective, generic skills are acquired through completing a variety of tasks in a range of work contexts. Classroom contexts are limited as are the scope of tasks for execution. There is an assumption that learning the theory of teamwork and then working on a team assignment within a university setting provides students with some teamwork skills that transfer into the workplace setting. However, research evidence suggests knowledge gained in the classroom does not become usable at work without further learning in the workplace (Eraut 2002). Eraut adds that acquired knowledge only has meaning once used; and its meaning is strongly influenced by previous contexts of use. The contextual nature of employability skills (particularly within practical judgement) moves focus from skills acquisition to professional development. From this standpoint, the development of professionals is seen as a life-long endeavour where educational and workplace settings contribute various formal and informal admixtures to shaping the individual. Professional education shifts thinking from training the individual mind to the social setting in which the individual is situated (Gonczi 2004)

As co-op programs are located in the workplace, they provide rich environments for learning and developing generic employability skills. However, many co-op programs struggle for educational recognition and overall viability. Also, there is little written on the learning value of co-op programs. Much of the research literature on co-op tends to reflect the 
practitioners' orientation that is largely focused on the effects of co-op programs on the personal growth and career development aspects of students. As a result the nature of learning in co-op education is not well understood (Ricks et al. 1993).

Each co-op work placement sits within an organisation where the opportunities for learning are influenced by personal, interpersonal, institutional, social and historical factors (Foley 2004). The nature of learning in workplaces has implications for designing a co-op management system to support the co-op learning experience.

\section{IMPLICATIONS FOR DESIGN}

Research literature in the fields of adult learning, organisational learning and workplace learning expose ambiguities, diversities and complexities associated with learning in the workplace. How adults learn can be seen to be influenced by a highly complex set of variables. These variables may be loosely grouped across three overlapping dimensions: the contextual dimension, the social dimension and the learning dimension. A number of variables specific to our discussion on professional development and learning are identified.

1. The contextual dimension includes the micro contexts of the organisation. External political, economical and technological forces drive an organisation's strategies. These strategies in turn drive its internal policy, culture, structure, processes and learning orientation. This learning orientation promotes or discourages a learning culture within the company and influences how managers, supervisors and employees share knowledge. Also the type of industry the organisation is involved in, influences the nature of the learning required and how learning is perceived (Smith and Sadler-Smith 2006).

It cannot be assumed that all organisations have a learning environment with resources and personnel in place to support the coop student. Nor can it be supposed that the student will learn just by being in the workplace. Through discussions between the organisation offering the work placement and the university, each coop placement can be tailored to not only accommodate the needs of the workplace but the learning needs of the student.

2. The social dimension includes internal and external stakeholders, their interactions and relationships. The assumptions, expectations and concerns held by the stakeholders towards learning, impact the design and implementation of learning programs. Good relationships between all parties depends on clear agreements, two-way, open communications; learning and mentoring support for students; advisory support for workplace supervisors; and a recognition of the value of an ongoing relationship between all parties (Lyons 2007, Gamble et al. 2007, Howe and Patrick 2007). 
3. The learning dimension brings together the factors regarding the learners and their contexts within the learning program. Learning can be formal, non-formal, informal and incidental (Foley 2004). However, most workplace learning occurs informally, but consciously through experience, or incidentally and unconsciously (Eraut et al. 1998). This means that measurement of learning and capturing individual learner progress is fraught with complexity. The Dreyfus Model of Skill Acquisition charts the incremental changes of a professional over five levels of proficiency: novice, advanced beginner, competent, proficient and expert (Benner 1982). Benner and Smith and SadlerSmith (2006) found that the learning needs of professionals varies according to their stage of professional development. Novices and advanced beginners require more learning support and scaffolding which decreases as they became more expert.

Most students in a co-op placement are at the novice stage of professional development and require guided instructions, "handholding", recognition and affirmation from supervisors and colleagues. Also students should be encouraged to be proactive and take responsibility for their own learning and professional development. Reflective practices can be encouraged through planned curricula (integrated with the university program), individual work and learning plans; and regular performance reviews and feedback.

This brief discussion touches on some of the complexities of workplacerelated learning. The co-op placement offers a unique learning opportunity for students. However, a successful learning program in the co-op workplace is the shared responsibility of the student, the employer and the university and is most successful with the active involvement of all parties. Martin in Howe and Patrick (2007) observes the best co-op placements are those where industry and universities are seen as equal partners involved in the planning of the overall experience and student's professional development

Information systems designed to manage the contextual, social and learning dimensions of co-op placements do not currently exist in normal university settings. The requirements to develop partnerships and manage relationships would imply facilities such as those found in customer relationship management systems. The system would also require the ability to capture and organise data arising outside the university in varied industry settings. Learning also needs to be monitored in a situation where formal assessment is not appropriate.

\section{TOWARDS A SYSTEM MODEL}

It is proposed that a co-op management system designed to promote the learning and development of employability skills, should support the following processes: building and cultivating partnerships between industry and the university; monitoring relationships between students and their 
workplace supervisors; facilitating learning and development of employability skills; and managing a cycle of continuous quality improvement.

In the next section, the extent to which these processes feature in an existing co-op program is investigated.

\section{IMPLICATIONS FOR PRACTICE}

The Bachelor of Business in Business Information Systems (BBBIS) at RMIT University is a 4 year degree that includes a mandatory 12-month industry placement in the third year. The co-op program has been running for over 19 years and has gone through a number of iterations. Experiential learning has always been considered an important aspect of the co-op year. However there has been a general assumption that students learn by "osmosis" with little contact required from the University during the student's placement. The past few years has seen a shift in thinking by the School (and the University) on the unique learning opportunities offered by a workplace setting. The co-op program is now seen as an integral part of the whole BBBIS program curriculum with a number of academics and administrative personnel now involved in its management and delivery. There are roughly 90 students in co-op placements at any one time.

Currently a number of manual and automated systems are employed to manage and deliver the Co-op program. These systems are investigated against the processes proposed in our systems model for the purpose of identifying design, development and implementation issues that require consideration when developing information systems for managing co-op programs.

\subsection{Building and cultivating partnerships between industry and university}

Jobs are sourced from new and existing employers (usually through email and phone calls from/to the Co-op Manager); or through students own job search efforts. Prospective employers are oriented to the Co-op program and the expectations of their participation outlined. Co-op jobs coming into the School are vetted for their suitability. At a minimum each job needs to be a full-time position; be engaged with information technology skills development; and be allocated a workplace supervisor.

Across the University, there are also a number of separate databases holding industry contact data about alumni, research partnerships and co-op employers that have the potential for developing further job opportunities. However, individuals, programs and schools are reluctant to share contact details with other parts of the University for fear of jeopardising their current relationships. Investigations are underway to identify ways the various databases can be linked without effecting individual relationships. 


\subsection{Monitoring relationships between students and their workplace supervisors}

Each student is allocated an academic supervisor (or "relationship manager") who visits the student at the start, middle and end of the placement. The co-op site visits are an opportunity for all the stakeholders to discuss expectations, review progress, give feedback and identify any issues or concerns.

Co-op site visits are scheduled through emails, phone calls, electronic calendars and spreadsheets. Three data capture forms are sent to the workplace supervisor prior to each site visit - the Memorandum of Understanding (refer to Appendix A), the Mid-Term Co-op Student Workplace Performance Appraisal, and the Final Co-op Student Workplace Performance Appraisal. These forms are designed to promote awareness of the workplace supervisor's involvement in the development of the student's employability skills during the placement period; to promote feedback to the student on their performance; and to discuss career directions. Co-op Site Visit forms are completed and emailed after each visit. Any concerns or issues are flagged for action by the Co-op Office.

The School maintains its own MS Access database and stores data on employers, students, student job applications, and employment details, as well as recording all interactions between the various stakeholders. The current system does not allow students, workplace supervisors or university staff (the data sources) to input co-op data from off-campus locations.

\subsection{Facilitating the learning and development of employability skills}

During the co-op preparation classes, students are made aware of the DEST set of employability skills as part of their resume writing exercises. Once they start co-op, students are placed in teams with other co-op students. Co-op student mentors (volunteers sourced from final year students or alumni) are allocated to each team to encourage students to share stories, concerns and achievements. Students meet on a monthly basis to participate in facilitated professional development discussions and activities.

Student performance appraisals are carried out at during and at the end of the placement in order to chart employability skills development (refer Appendix B). Workplace supervisors provide input into the student's final assessment grade.

The course website is designed around academic and student requirements. It supports student reflection (e-journals blogs); team discussions; open forums; learning resources; and assessment information. It does not however allow for ready access by non-RMIT participants such as workplace supervisors, alumni and other industry-based individuals. 


\subsection{Managing a cycle of continuous quality improvement}

Feedback is sought from all stakeholders in three key areas: the delivery of the co-op experience; the administration and management of the co-op program; and the relevance of BBBIS program curriculum to the co-op year. The feedback is collected through paper-based forms (refer Appendix C); emails; student journals and reflection papers; and face-to-face meetings. There is no electronic repository for capturing feedback data for analysis and just-time reporting. Improvements are implemented on an ad-hoc basis.

There are a number of separate, disparate systems involved in the management of the current BBBIS Co-op program. The above discussion raises a number of issues and concerns and highlights the need for a more collaborative, holistic approach to the design, development and management of co-op management systems that cross program, School and University boundaries. Information systems supporting and managing co-op partnerships should:

- Allow for and support, two way communication and discussion between all stakeholders (within and outside the university);

- Provide on-line learning resources for all stakeholders;

- Permit data to be captured directly from data sources, located at on and off-campus locations, in a format that allows analysis and reflection by key stakeholders;

- Support local and remote, multi-user access to relevant databases;

- Allow just-in-time reporting; and

- Be responsive to changes and improvements.

\section{CONCLUSIONS}

Co-op programs have been around for over 100 years yet have struggled for recognition in university curricula. Research studies purport knowledge and skills gained in the classroom do not become usable without further learning in the workplace. It is argued, that generic employability skills, in particular, are developed through completing tasks in a variety of situations. Co-op programs are located in workplaces and offer a rich source of learning contexts. A curriculum integrating workplace and classroom learning suggests a good foundation for on-going professional development.

The most successful co-op placements are those where industry and universities are seen as equal partners involved in the planning of the overall experience and in monitoring and guiding day to day development. Information systems supporting and managing these partnerships need to allow for and support open, two-way communications and discussions between all stakeholders; contain relationship management systems; track student placements and monitor progress of employability skills development; provide on-line learning resources and mentoring support; permit data to be captured directly from data sources, located at on and off-campus locations, in a format that allows analysis and reflection by key stakeholders; 
support multi-user, remote access to relevant databases; allow just-in-time reporting; and be responsive to changes and improvements. New industry partnerships can be cultivated at a number of levels, within and outside the university. Systems that track previous industry engagements in research, co-op and projects endeavours have the potential to promote stronger links with industry.

Co-op programs provide a bridge between universities and industry and are in a unique position for building sustainable programs, developing existing industry relationships and promoting new partnership opportunities. The design, development and management of co-op systems should be considered beyond program, School and University boundaries.

\section{REFERENCES}

BECKETT, D. \& HAGER, P. (2002). Life, Work and Learning: Practice in post modernity. London \& New York, Routledge.

BENNER, P. (1982). From Novice to Expert. The American Journal of Nursing, 82, 402-407.

CATES, C. \& JONES, P. (1999). Learning outcomes: The educational value of cooperative education, Colombia, MD, Cooperative Education Association.

COLL, R. \& EAMES, C. (2004). Current Issues in Cooperative Education. IN EAMES, R. K. C. A. C. (Ed.) International Handbook for Cooperative Education. Boston, USA. World Association for Cooperative Education, Inc.

DEST (2002). Employability Skills for the Future. Commonwealth of Australia.

DETYA (2000). Employer Satisfaction with Graduate Skills: Research Report 99(7), Feb 2000 Evaluations and Investigations Program. Higher Education Division (Ed.). Canberra.

DRESSLER, S. \& KEELING, A. E. (2004). Student Benefits of Cooperative Education. IN EAMES, R. K. C. A. C. (Ed.) International Handbook for Co-operative Education. Boston, USA, World Association for Cooperative Education, Inc.

ERAUT, M. (2002). The interaction between qualifications and work-based learning. IN K. EVANS, P. H., L. UNWIN (Ed.) Work to Learn. London, Kogan Page.

ERAUT, M. E., Alderton, J., COLE, G. \& SENKER, P. (1998). Development of Knowledge and Skills in Employment. East Sussex, UK, University of Sussex.

FOLEY, G. (2004). Introduction: The state of adult education and learning. IN FOLEY, G. (Ed.) Dimensions of Adult Learning: Adult education and training in a global era. Crows Nest, NSW, Allen \& Unwin.

GAMBLE, N., THOMPSON, K. \& ZDENKOWSKI, S. (2007). Sustainable Partnerships and Meeting Expectations: What Keeps Industry Coming Back for More? Proceeding for the Asia-Pacific Conference on Cooperative Education. Singapore, WACE. 
GONCZI, A. (2004). The new professional and vocational education. IN FOLEY, G. (Ed.) Dimensions of Adult Learning: Adult education and training in a global era. Crows Nest, NSW, Allen \& Unwin.

HOWARD, A. (2005). Cooperative Education and Internships at the Threshold of the Twenty-First Century. IN LINN, P. L., HOWARD, A. \& MILLER, E. (Eds.) Handbook for Research in Cooperative Education and Internships. Mahwah, NJ, Lawrence Erlbaum Associates.

HOWE, C. \& PATRICK, C. (2007). The importance of the customer relationship to Industry in Work-integrated-learning programs. Proceeding for the Asia-Pacific Conference on Cooperative Education. Singapore, WACE.

JANCAUKAS, E., ATCHISON, M., MURPHY, G. \& ROSE, P. (1999). Unleashing the potential of work-integrated learning through professional trained academic and industry supervisors. World Association of Cooperative Education.

LYONS, F. (2007). Developing Sustainable Education Partnerships with Industry. Proceeding for the Asia-Pacific Conference on Cooperative Education. Singapore, WACE.

MULTIMEDIAVICTORIA (2005). ICT Skills Snapshot: The State of ICT Skills in Victoria. Melbourne, Department of Infrastructure.

REEDERS, E., ATCHISON, M., POLLOCK, S. \& RIZZETTI, J. (1999). Structured work experience: Habit, cargo cult or Cinderella? Practicum Colloquium. Flinders University, SA.

RICKS, F., CUTT, J., BRANTON, G., LOKEN, M. \& VAN GYN, G. (1993). Reflections on the cooperative education literature. Journal of Cooperative Education, 29, 6-23.

SMITH, P. J. \& SADLER-SMITH, E. (2006). Learning in Organizations: Complexities and diversities, London and New York, Routledge.

WARYSZAK, R. Z. (2000). Before, during and after: International perspective of students' perceptions of their cooperative education placements in the tourism industry. Journal of Cooperative Education, 35.

WEISZ, M. (1995). How to motivate and train academic supervisors: Find the missing link to the partnership in co-operative education. 9th World Conference on Co-operative Education. Jamaica. 


\section{Appendix A - Memorandum of Understanding}

\begin{tabular}{|c|c|}
\hline \multicolumn{2}{|c|}{ Agreement regarding the Co-operative Employment / Internship Program } \\
\hline 1. & The employment period for a student needs to be a minimum of 40 weeks full time. \\
\hline 2. & $\begin{array}{l}\text { During the industry placement, students are employees of the organisation and are required to observe the same standards and } \\
\text { conditions of work within the company as would any other regular employees, or face disciplinary action as would any other } \\
\text { employee within the organisation (warnings, directives and dismissal). The student also risks failing their Co-operative Employment } \\
\text { Year. }\end{array}$ \\
\hline 3. & $\begin{array}{l}\text { If there are any problems that are inhibiting the student from reaching their expected potential, RMIT should be contacted and after } \\
\text { consultation, undertake appropriate action. }\end{array}$ \\
\hline 4. & $\begin{array}{l}\text { The employer should arrange for the payment of tax \& superannuation, and provide Workcover, professional indemnity insurance } \\
\text { and ensure all standard Australian/Victorian employment conditions apply. }\end{array}$ \\
\hline & $\begin{array}{l}\text { The employer agrees that the student is working in areas that are predominantly ( 90\%) in software, and that students have an IT } \\
\text { qualified or experienced supervisor to lead them throughout the placement. }\end{array}$ \\
\hline & Students must complete assignments throughout the year. These are expected to be completed outside business hours. \\
\hline & $\begin{array}{l}\text { Students are requested to attend monthly forums (outside normal working hours) at RMIT University during the year as a class } \\
\text { group (not applicable to interns outside Melbourne). }\end{array}$ \\
\hline & $\begin{array}{l}\text { An RMIT representative agrees to attend the workplace at a minimum, three times during placement to appraise and discus } \\
\text { progress of the internship. RMIT will speak openly to employers, supervisors and students regarding questions, problems or issue } \\
\text { concerning the internship. }\end{array}$ \\
\hline \multicolumn{2}{|c|}{ I have read and accept the Agreement regarding the Co-operative Employment / Internship Program } \\
\hline \multicolumn{2}{|c|}{ Employer Representative } \\
\hline \multicolumn{2}{|c|}{ Name } \\
\hline \multicolumn{2}{|c|}{ Position } \\
\hline \multicolumn{2}{|c|}{ Signature } \\
\hline \multicolumn{2}{|c|}{ Date } \\
\hline \multicolumn{2}{|c|}{ Student } \\
\hline \multicolumn{2}{|c|}{ Name } \\
\hline \multicolumn{2}{|c|}{ Signature } \\
\hline \multicolumn{2}{|c|}{ Date } \\
\hline
\end{tabular}

\section{Appendix B - Student Performance Review Forms}

\begin{tabular}{|c|c|c|c|c|}
\hline & Below Average & Average & Above Average & Outstanding \\
\hline Interest in work & $\begin{array}{l}\text { Interest } \\
\text { spasmodic, } \\
\text { occasionally } \\
\text { enthusiastic } \\
\end{array}$ & $\begin{array}{l}\square \text { Satisfactory } \\
\text { amount of interest }\end{array}$ & $\begin{array}{l}\square \text { More than } \\
\text { average amount of } \\
\text { interest and } \\
\text { enthusiasm }\end{array}$ & $\begin{array}{l}\square \text { High interest, very } \\
\text { enthusiastic. Takes pride in } \\
\text { doing work well }\end{array}$ \\
\hline $\begin{array}{l}\text { Problem solving } \\
\text { skills }\end{array}$ & $\begin{array}{l}\square \text { Exhibits } \\
\text { marginal problem } \\
\text { solving ability }\end{array}$ & $\begin{array}{l}\square \text { Satisfactory } \\
\text { problem solving } \\
\text { ability }\end{array}$ & $\begin{array}{l}\square \text { Adept at } \\
\text { solving problems }\end{array}$ & $\begin{array}{l}\square \text { Highly adept and } \\
\text { innovative }\end{array}$ \\
\hline $\begin{array}{l}\text { Interpersonal } \\
\text { skills }\end{array}$ & $\begin{array}{l}\square \text { Sometimes } \\
\text { antagonises others, } \\
\text { tends to be } \\
\text { uncommunicative }\end{array}$ & $\begin{array}{l}\square \text { Relations with } \\
\text { others are } \\
\text { harmonious at } \\
\text { most times } \\
\end{array}$ & $\begin{array}{l}\square \text { Works well } \\
\text { with associates }\end{array}$ & $\begin{array}{l}\text { Always works in } \\
\text { harmony with others, an } \\
\text { excellent team worker. }\end{array}$ \\
\hline Creativity & $\begin{array}{l}\square \text { Rarely offers } \\
\text { new ideas }\end{array}$ & $\begin{array}{l}\text { Has average } \\
\text { imagination }\end{array}$ & $\begin{array}{l}\text { Frequently } \\
\text { offers new ideas, } \\
\text { imaginative }\end{array}$ & $\begin{array}{l}\text { Continually offers new } \\
\text { ideas, extremely } \\
\text { imaginative }\end{array}$ \\
\hline Desire to learn & $\begin{array}{l}\square \text { Requires more } \\
\text { than average } \\
\text { instruction }\end{array}$ & $\begin{array}{l}\square \text { Grasps } \\
\text { instruction with } \\
\text { average ability }\end{array}$ & $\begin{array}{l}\square \text { Usually quick } \\
\text { to understand and } \\
\text { learn }\end{array}$ & $\begin{array}{l}\square \text { Exceptionally keen and } \\
\text { alert }\end{array}$ \\
\hline $\begin{array}{l}\text { Work Quality, } \\
\text { Attention to detail }\end{array}$ & $\begin{array}{l}\square \text { Make many } \\
\text { errors }\end{array}$ & $\begin{array}{l}\square \text { Usually } \\
\text { accurate }\end{array}$ & $\begin{array}{l}\square \text { Is almost } \\
\text { always accurate }\end{array}$ & $\begin{array}{l}\square \text { Work is always } \\
\text { accurate }\end{array}$ \\
\hline Work Quantity & $\begin{array}{l}\square \text { Does just } \\
\text { enough to get by }\end{array}$ & $\begin{array}{l}\square \text { Volume of work } \\
\text { is satisfactory }\end{array}$ & $\begin{array}{l}\square \text { Produced a good } \\
\text { volume of work }\end{array}$ & $\begin{array}{l}\square \text { Very industrious, does } \\
\text { more than required }\end{array}$ \\
\hline Dependability & $\begin{array}{l}\square \text { Sometimes } \\
\text { needs prompting }\end{array}$ & $\begin{array}{l}\square \text { Usually takes } \\
\text { care of tasks and } \\
\text { completes them } \\
\text { fairly promptly }\end{array}$ & $\begin{array}{l}\square \text { Requires little } \\
\text { supervision and } \\
\text { completes tasks } \\
\text { promptly }\end{array}$ & $\begin{array}{l}\square \text { Requires absolute } \\
\text { minimum supervision }\end{array}$ \\
\hline Work knowledge & $\begin{array}{l}\text { Lacks know- } \\
\text { ledge of some } \\
\text { phases of work }\end{array}$ & $\begin{array}{l}\square \text { Moderately } \\
\text { informed }\end{array}$ & $\begin{array}{l}\square \text { Understood } \\
\text { most work } \\
\text { challenges presented }\end{array}$ & $\begin{array}{l}\square \text { Understands all phases } \\
\text { of work }\end{array}$ \\
\hline $\begin{array}{l}\text { Communication } \\
\text { Oral }\end{array}$ & $\begin{array}{l}\square \text { Sometimes } \\
\text { encounters } \\
\text { difficulty in } \\
\text { speaking clearly } \\
\text { and concisely }\end{array}$ & $\begin{array}{l}\square \text { Satisfactory } \\
\text { verbal skills }\end{array}$ & $\begin{array}{l}\text { Clear well } \\
\text { organised and } \\
\text { clearly understood }\end{array}$ & $\begin{array}{l}\square \text { Exceptional verbal } \\
\text { expression. }\end{array}$ \\
\hline $\begin{array}{l}\text { Communication } \\
\text { Written }\end{array}$ & $\begin{array}{l}\square \text { Sometimes } \\
\text { encounters difficulty } \\
\text { in writing clearly } \\
\text { and concisely }\end{array}$ & $\begin{array}{l}\square \text { Satisfactory } \\
\text { written skills }\end{array}$ & $\begin{array}{l}\square \text { Clear well } \\
\text { organised and } \\
\text { clearly understood }\end{array}$ & $\begin{array}{l}\square \text { Exceptional written } \\
\text { expression. }\end{array}$ \\
\hline
\end{tabular}




\section{Appendix C - Workplace Supervisor \& Student Feedback}

(Excerpt from Student Performance Forms)

Overall Level of Satisfaction

\begin{tabular}{|ll|}
$\square$. Outstanding & Major strengths are: \\
$\square$. Very good & 1. \\
$\square$. Satisfactory & 2. \\
$\square$. Unsatisfactory & Areas for improvement: \\
& 1. \\
\hline
\end{tabular}

If employment was available would you support the placement of this student in a permanent position $\begin{array}{lll}\text { within your company? } & \square . \\ & & \text {. Nes. No }\end{array}$

\section{Other Supervisor Comments}

I have discussed this evaluation with the student. . $\square$. Yes. . $\square$. No

Supervisor's signature: Date:

\section{Student Comments}

Were your personal expectations for growth and development during this work experience:

$\square$.Accomplished. .... $\square$.Somewhat accomplished..... $\square$.Not Accomplished

\section{Other Student Comments}

Student's signature:

Date:

Feedback to BBBIS Program Team

Did you find the student's knowledge or skills lacking in any particular area? $\square$.Yes . $\square$.No If so in what areas.

\section{Feedback to Co-op Education Team}

Could the student have being prepared for the work placement in some way? . $\square$.Yes . $\square$.No

If so, please specify

Is there a possibility of a further Co-operative Education Placement next semester/year? $\square$.Yes . $\square$.No

Contact Name:

Contact Details:

RMIT, School of Business Information Technology 